\title{
Patrycja Rutkowska, Dominik Tylka
}

\section{Sprawozdanie z konferencji naukowej „Relacje religii i polityki jako przedmiot badań politologii”}

\author{
Warszawa, 30.11.-1.12.2017 r.
}

W dniach 30 listopada i 1 grudnia 2017 r. na Uniwersytecie Kardynała Stefana Wyszyńskiego w Warszawie odbyła się konferencja naukowa pt. Relacje religii i polityki jako przedmiot badań politologii. Wzięło w niej udział blisko sześćdziesięciu prelegentów, reprezentujących ośrodki naukowe z Anglii, Indii, Izraela, Polski, Serbii, Słowacji, Włoch i Tanzanii. Konferencja została zorganizowana przez Instytut Politologii UKSW w Warszawie we współpracy z Instytutem Stosunków Międzynarodowych Uniwersytetu Warszawskiego, Instytutem Politologii Uniwersytetu Opolskiego, Instytutem Politologii Uniwersytetu Zielonogórskiego oraz Instytutem Politologii Uniwersytetu Marii CurieSkłodowskiej w Lublinie. W skład Rady Programowej weszli przedstawiciele polskiego środowiska naukowego skupionego wokół problematyki relacji religii i polityki, tj.: Aniela Dylus, Wojciech Jakubowski, Joanna Kulska, Maria Marczewska-Rytko, ks. Piotr Mazurkiewicz, Ryszard Michalak, Anna Solarz, Radosław Zenderowski oraz Michał Gierycz.

U podstaw tego wydarzenia legło przekonanie, że rosnące zainteresowanie badaniem sprzężenia religii i polityki oraz postulaty utworzenia subdyscypliny „politologia religii” w wielu prestiżowych ośrodkach akademickich powinny zachęcać do pogłębionych rozważań nad pytaniami teoretyczno-metodologicznymi. Stąd za główny cel konferencji organizatorzy uznali środowiskową refleksję nad teorią i metodologią badania religii na gruncie nauk o polityce, łącząc go z prezentacją efektów najnowszych badań nad relacjami religii i polityki. W konsekwencji tak określonego celu naukowego, w toku obrad poszukiwano odpowiedzi na pytania zogniskowane w odniesieniu do: 
- konsekwencji uwzględnienia roli religii dla badań politologicznych i tożsamości dyscypliny: czy/dlaczego potrzeba odniesienia do religii $\mathrm{w}$ ramach nauk o polityce? Co wnosi badanie religii do tożsamości dyscypliny ufundowanej w dobie paradygmatu pozytywistycznego?;

- sposobu ujęcia religii specyficznego dla nauk o polityce: co wyróżnia podejście do religii na gruncie politologii? Czy można pokusić się o politologiczną definicję, czy chociaż pryzmat patrzenia na religię?;

- metod prowadzonych badań: jak rozumieć postulat bezstronności, gwarantującej obiektywizm badawczy? Które paradygmaty badawcze stosowane w naukach o polityce uznać można za adekwatne do badania fenomenów religijnych i jakie są ich ew. ograniczenia?.

Ze względu na niezwykle bogaty i interesujący obszar tematyczny, konferencja naukowa została podzielona na dwa dni podczas których zorganizowano po dwie sesje plenarne i trzy - toczące się równolegle do siebie - panele tematyczne. Ponadto, pierwszego dnia konferencji uczestnicy mieli okazję przedyskutować wystąpienie Jeffreya Haynes'a (key-note speech) - wybitnego specjalistę z zakresu religii i stosunków międzynarodowych oraz religii i polityki. W związku z faktem, że problemy teoretyczno-metodologiczne dyskutowane byłe w ramach sesji plenarnych, na nich koncentruje się niniejsze sprawozdanie.

Pierwsza sesja plenarna, moderowana przez prof. Zbigniewa Stawrowskiego (UKSW) podejmowała temat: Nauka o polityce a fenomen religii. Otwierający referat pt. 25 years of politology of religion wygłosił prof. Miroljub Jevtić z Uniwersytetu w Belgradzie. Autor postawił przed sobą zadanie wprowadzenia uczestników konferencji w historię badań religii na gruncie nauk politycznych. Wskazał przy tym na zastanawiający fenomen odnoszący się do badania przez światowe ośrodki naukowe relacji religii z polityką. Mianowicie, logika panującego w drugiej połowie XX w. na Zachodzie liberalizmu, a na Wschodzie marksizmu nie sprzyjały poświęcaniu religii należnej jej uwagi do tego stopnia, że nawet po powstaniu państw wprost ufundowanych na religii - Pakistanu i Izraela, ośrodki politologiczne kontynuowały logikę desinteressment dla kwestii religii w procesach politycznych. Co więcej, choć po ataku na World Trade Center powinny zmienić to podejście, ciężko mówić o diametralnej zmianie sytuacji. Wymiary problematyczności takiego podejścia do religii w politologii omówił w swoim wystąpieniu ks. prof. Piotr Mazurkiewicz z Uniwersytetu Kardynała Stefana Wyszyńskiego. W swoim wystąpieniu poszukiwał odpowiedzi na pytanie: Co politolog powinien wiedzieć o religii?, dowodząc, że choćby po doświadczeniach „Jesieni Ludów” i „Arabskiej Wiosny” ciężko dalej uznawać za wątpliwe, że religia ma istotne znaczenia dla przebiegu procesów politycznych 
i społecznych. W konsekwencji, dla politologa istotne powinny być m.in. pytania o to: z jaką religią mamy do czynienia?; w jaki sposób dana religia jest przeżywana?; czy to jest wiara szukająca zrozumienia czy też wiara przeżywana w sposób fideistyczny? Prelegent zaznaczył przy tym, że choć politolog bada jedynie niewielki fragment zjawiska religii, tzn. funkcje zastępcze religii a nie jej funkcje własne, to musi być świadomy również tych ostatnich. W kontekście konieczności przywrócenia refleksji nad religią miejsca w analizie politycznej, ks. Jacek Grzybowski z Instytutu Filozofii UKSW podjął próbę zmierzenia się z problemem rozumienia postulatu obiektywizmu naukowego w kontekście badania religii na gruncie nauk o polityce. W swoim wystąpieniu Roszczenia światopoglądowe w pracy politologów - zarzut czy normalność? zauważył, że ciężko uznać za zasadne oczekiwanie, by wierzący politolog dystansował się od racji religijnych, które stanowią część jego życia. Nie w ateizacji podejścia do świata upatrywać należy kryteriów naukowości, a w racjonalności (rozumności) argumentacji. W konsekwencji, jak podkreślił prelegent, „politolog powinien rozpoznać w sposób najpełniejszy swoje racje światopoglądowe, właściwie je nazwać i obiektywizować je w języku poprzez odniesienie się do takich argumentów, takich słów, takich przykładów, które byłyby wspólne dla naszego spotkania”.

Dwa referaty pierwszej sesji poświęcone zostały ukazaniu znaczenia religii dla perspektyw badawczych nauk o polityce. Prof. Aniela Dylus z Uniwersytetu Kardynała Stefana Wyszyńskiego w Warszawie w referacie Elementy manichejskie w polityce. Perspektywa teologii chrześcijańskiej, poszukiwała manichejskich wątków w praktyce i teorii politycznej. Projekcję logiki, którą za ks. prof. Tischnerem określiła mianem „neomanichejskiej”, referentka dostrzegła w polskiej polityce przynajmniej od lat 70. XX w. Postawiła tezę, że właśnie uwzględnienie perspektywy neomanichejskiej może wyjaśniać np. współczesną kontestację idei Okrągłego Stołu, który - jako wyraz kompromisu - nie mieści się w manichejskiej logice. Prof. Tomasz Żyro z Uniwersytetu Warszawskiego w referacie Sacrum a polityka, podjął próbę odpowiedzi na pytanie, czy zakorzeniony w tradycji judeochrześcijańskiej impuls uszlachetniania polityki jest wciąż obecny w naszej kulturze. Za przejawy przenikania sacrum do polityki T. Żyro uznał m.in. uświęcanie praw człowieka czy zasady tolerancji. W takim ujęciu kryzys polityczny można postrzegać jak zdeformowany akt nawrócenia, a przywrócenie ładu mogłoby się dokonać przez wskazanie i napiętnowanie symbolicznego kozła ofiarnego.

Po zamknięciu pierwszej sesji plenarnej, uczestnicy konferencji mieli okazję usłyszeć key-note speech gościa honorowego konferencji, prof. Jeffreya Haynesa z London Metropolitan University. W wystąpieniu zatytułowanym The United Nations Alliance of Civilizations: Improving inter-civilisational relations? prelegent szczególną uwagę poświęcił działalności 
Alliance of Civilization. Do jego powstania w 2005 r. przyczyniły się przede wszystkim dwa wydarzenia: 1) atak na World Trade Centre w 2001 r., 2) atak terrorystyczny w madryckim metrze w $2004 \mathrm{r}$. Od tej pory w środowisku międzynarodowym zaczęto zauważać, że wyłącznie sekularna wizja świata nie jest właściwa, a pogląd, że polityka międzynarodowa jest niezależna od religii należy poddać ponownej refleksji. Po przeanalizowaniu struktury celów i zakresu kompetencji organizacji Alliance Civilization, prelegent ocenił jednak negatywnie możliwość jej skutecznego działania w odniesieniu do tworzenia właściwego dialogu międzykulturowego. Komentarze do wystąpienia prof. Haynesa wygłosili prof. Roman Kuźniar (UW), oraz ks. prof. Piotr Mazurkiewicz (UKSW), otwierając dyskusję nad tezami wystąpienia honorowego gościa moderowaną przez prof. Jana Grosfelda.

Druga sesja plenarna została zatytułowana: Metody badawcze politologii a religia. Poprowadził ją ks. dr Piotr Burgoński (UKSW). Jako pierwszy, głos zabrał dr hab. Maciej Potz z Uniwersytetu Łódzkiego. W swoim referacie zatytułowanym: Politologia religii jako nowy paradygmat badania roli religii w polityce prelegent przedstawił słabości paradygmatu badania relacji religii i polityki przez pryzmat związku państwo-kościół, Dlatego też postulował zastąpienie powyższego modelu nowym paradygmatem - politologią religii. Opierać ma on się m.in. na założeniach, że: 1) religia jako zjawisko społeczne (też jako zbiór wierzeń) może motywować ludzi do różnych zachowań i postaw politycznych, przez co koncentruje swoją uwagę na swoich efektach w sferze polityki bez rozstrzygania w co ludzie wierzą; 2) wierzenia religijne traktowane jako funkcjonalne odpowiedniki ideologii politycznych mogą pełnić istotne funkcje w teokratycznych i nieteokratycznych systemach politycznych. Wystąpienie kolejnego prelegenta, prof. Łukasza Młyńczyka z Uniwersytetu Zielonogórskiego zostało zatytułowane: Politologia o religii w perspektywie umiarkowanego naturalizmu metodologicznego. Zdaniem badacza, powszechnie posługujemy się użytkową, społeczną definicją religii opierającą się na rozumieniu okoliczności jej wpływu na życie konkretnej zbiorowość, która może wytworzyć organizację polityczną społeczeństwa. Ciekawym spostrzeżeniem jest to, że użycie owej definicji prowadzi do otrzymania trójsegmentowego politycznego formatu religii o szczególnych właściwościach. Kolejnym z prelegentów był przybyły z Uniwersytetu w Belgradzie Marko Vekovic. W wystąpieniu Religion as mechanism of explaining political behavior za kluczowe dla związku religii i polityki uznał rozpoznanie, w jaki sposób aktorzy religijni, a więc instytucje, $\mathrm{w}$ tym przede wszystkim kościoły, mogą wpływać na zachowania polityczne członków swoich wspólnot oraz jak to robią. Przykładem takiej sytuacji jest m.in fenomen ludzi, opuszczających swe ojczyzny w celu dołączenia do jakiegoś konfliktu. Ostatnim prelegentem tej sesji był dr hab. Michał Gierycz z Uniwersytetu Kardynała Stefana Wyszyńskiego w Warszawie. W wystąpieniu zatytułowanym Religia a możliwości 
analizy systemowej, referent skupił się na odpowiedzi na trzy pytania, które uznał za szczególnie istotne z perspektywy metodologicznej: 1) Czy w metodologicznym korpusie politologii w ogóle jest miejsce na coś takiego jak politologia religii? 2) Czy paradygmat systemowy daje możliwość odpowiedniego uwzględniania religii, tak aby zachować jej specyfikę odróżniającą ją od fenomenów ideologicznych i stricte politycznych? 3) Jakie są ograniczenia paradygmatu systemowego w możliwościach jego aplikacji w kontekście religii i czy jest możliwe ich przezwyciężenie? W toku odpowiedzi na te pytania prelegent polemizował z tezą o konieczności redukcji wierzeń religijnych do fenomenów ideologicznych na gruncie politologii, prezentując analityczne możliwości tzw. „głębokiej analizy systemowej”.

Trzecia sesja plenarna została zatytułowana: Wymiary oddziaływania religii na politykę. Poprowadził ją dr hab. Sławomir Sowiński (UKSW). Jako pierwszy wystąpił przybyły $\mathrm{z}$ Uniwersytetu Ben Gouriona prof. Fred Lazin $\mathrm{z}$ tematem The changing context of Judaism and Jews in American politics: from 1930s to the Trump era. Wystąpienie miało na celu przedstawienie słuchaczom, jak zmieniały się relację między amerykańską diasporą Żydów a tzw. głównym nurtem polityki Stanów Zjednoczonych. Jak podkreślał, zmianom w tym zakresie zawsze towarzyszyło pewne przesilenie polityczne. Prof. Bogdan Szlachta z Uniwersytetu Jagiellońskiego, w wystąpieniu O prawie naturalnym jako ewentualnym normatywnym punkcie odniesienia w procesach prawodawczych, dowodził, że choć namysł nad prawem naturalnym oraz nad jego wagą dla stanowienia norm prawnych i prowadzenia polityk publicznych jest wzmożony w Kościele już od czasu pontyfikatu Leona XIII, jednak w polityce zaznacza się wyraźnie trend odwrotny. W kolejnym wystąpieniu prof. Stanisław Mocek z Collegium Civitas podjął kwestię Wzloty i upadki religii politycznych. Zarys koncepcji $i$ jej polityczne emanacje prelegent zwrócił uwagę, że religie polityczne zazwyczaj są związane $\mathrm{z}$ jakimiś sytuacjami wręcz traumatycznymi. Jest to wówczas forma reakcji na poważne kryzysy cywilizacyjne, szczególnie widoczne w XX w. Polityka bowiem, która poprzez odejście od elitaryzmu otworzyła się na rzesze obywateli, wypełniła przestrzeń społeczną w taki sposób, w jaki w przeszłości robiła to wyłącznie religia. Ostatnim prelegentem w trzeciej sesji plenarnej był prof. Radosław Zenderowski z Uniwersytetu Kardynała Stefana Wyszyńskiego. Swój referat, zatytułowany Między etnicyzacją religii a sakralizacja etnosu, poświęcił analizie relacji polityki z nacjonalizmem i religią. Swoje wystąpienie prelegent zakończył krótką analizą politycznego znaczenia świątyń, jako miejsc stanowiących niekiedy funkcjonalny odpowiednik słupów granicznych.

Czwarta i ostatnia sesja plenarna pt. Teoria politologii religii - wybrane problemy była moderowana przez dr hab. Michała Gierycza (UKSW). W wystąpieniu zatytułowanym 
Religia jako cześś geopolityki, prof. Jarosław Macała z Uniwersytetu Zielonogórskiego ukazał słabości obecnego stanu badań nad interakcjami religii i geopolityki, unikających - jego zdaniem - uznać istotności znaczenia religii dla procesów geopolitycznych. Dr Marcin Pomarański z Uniwersytetu Marii Skłodowskiej-Curie, w wystąpieniu pt. Religia polityki a religia polityczna, rozważał pytanie stawiane przez Emilio Gentile’a, dotyczące możliwości adaptacji kategorii „religii politycznej” do analizy współczesnych, wzajemnych relacji religii i polityki nie tylko w systemach totalitarnych i autorytarnych, ale także w systemach demokratycznych. Kolejny z prelegentów, prof. Krzysztof Gładkowski z Uniwersytetu Warmińsko-Mazurskiego w Olsztynie w wystąpieniu zatytułowanym Czy możliwe jest przezwyciężenie interdyscyplinarności $w$ badaniach religii $w$ politologii? odniósł się do konieczności uwzględnienia kwestii antropologicznej jako fundamentu badań nad religią w ramach nauk o polityce. Argumentował, że pozwolić może to przezwyciężyć logikę interdyscyplinarności tych badań. Ks. dr Tadeusz Jarosz z Uniwersytetu w Morogoro (Tanzania) przybliżył uczestnikom koncepcję „politologii eklezjalnej” jako sposobu poszukiwania adekwatnej perspektywy ujmowania Kościoła w badaniach politologicznych, a ks. prof. Janusz Węgrzecki z Uniwersytetu Kardynała Stefana Wyszyńskiego w Warszawie założenia „realistycznej politologii religii”.

Prowadzone dyskusje teoretyczno-metodologiczne uzupełniały panele równoległe poświęcone prezentacji najnowszych badań z zakresu politologii religii. Pierwszego dnia konferencji zaprezentowano wyniki badań skoncentrowanych w obszarach: „Religion in international relations” (moderator: dr Joanna Kulska, UO), „Wokół teorii sekularyzacji” (moderator: dr Marcin Pomarański, UMCS), „Chrześcijaństwo, Kościół, Europa” (moderator: dr Mariusz Sulkowski, UKSW), a drugiego wokół zagadnień: „Islam jako problem religijno-polityczny” (moderator: prof. Ryszard Michalak, UZ); „Religia na rubieżach Europy” (moderator: dr Anna Solarz, UW); „Drogi sekularyzacji” (moderator: dr Andrzej Rudowski, UKSW).

Konferencja ukazała szerokie i różnorodne spektrum badań prowadzonych w odniesieniu do politologii religii, jak również odsłoniła bogactwo możliwości teoretycznego i metodologicznego ugruntowania badań w tym obszarze. Jak się wydaje, otworzyła również pola współpracy między poszczególnymi badaczami. Dodać warto, że przebieg dyskusji po wystąpieniach ukazywał niekiedy, że rzeczywiście, jak zauważył prof. R. Zenderowski, „religia i polityka to dwie rzeczy, które w ludziach wzbudzają szczególne emocje”. Jednocześnie jednak potwierdzał, wyrażone w pierwszym panelu przez ks. prof. Jacka Grzybowskiego przekonanie, że właściwe nazwanie i zobiektywizowanie własnych przeświadczeń „poprzez odniesienie się do takich argumentów, takich słów, takich przykładów, które byłyby wspólne 
dla naszego spotkania”, pozwala na owocną i merytoryczną dyskusję. Kolejną okazję do jej prowadzenia organizatorzy obiecali stworzyć za dwa lata, na kolejnej konferencji teoretyczno-metodologicznej z zakresu „politologii religii”.

Patrycja Rutkowska - doktorantka na Wydziale Nauk Historycznych i Społecznych UKSW, magister administracji, europeistyki i stosunków międzynarodowych; członkini Polskiego Towarzystwa Nauk Politycznych i Polskiego Towarzystwa Studiów Międzynarodowych. Jej zainteresowania naukowe obejmują: sprzężenie religii i polityki w UE, ochrona dóbr kultury w konfliktach zbrojnych oraz europejską przestrzeń administracyjna.

Dominik Tylka - politolog, mgr, doktorant na Wydziale Nauk Historycznych i Społecznych UKSW. Jego zainteresowania badawcze obejmują: teorie i modele władzy, przywództwo polityczne w warunkach kryzysu, znaczenie ideologii i propagandy w sprawowaniu władzy, przemiany społeczno-polityczne w Europie Środkowo-Wschodniej w XIX i XX w. 